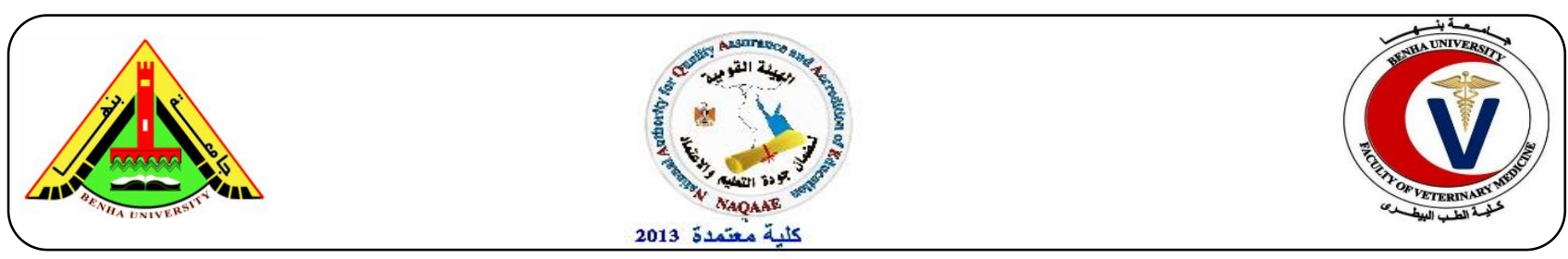

\title{
The Effect of Probiotics on Staphylococcus Aureus and E. Coli in Minced Meat
}

\author{
Hemmat M. Ibrahim¹, Reham A. Amin ${ }^{1}$, Khalid S. Tolba²and Amira A. Elokle ${ }^{2}$ \\ ${ }^{1}$ Food Hygiene and Control Department, Faculty of Veterinary Medicine - Benha University Egypt. \\ ${ }^{2}$ Animal Health Research Institute, Agriculture Research center, Dokki, Egypt.
}

\section{A B S T R A C T}

Nowadays, all interested parties in the field of food safety are shifted to use natural food preservatives instead of chemical ones which proved to have many draw backs either on human health or food composition. The present study was conducted to study the effect of using two probiotic strains (Lactobacillus acidophilus and Bifidobacteriumlactis) individually on the growth and survival of some food-borne pathogens represented by Staphylococcus aureus and Escherichia coli experimentally inoculated separately into fresh minced beef, previously gamma irradiated using $5 \mathrm{KGy}$ to be sure that samples were free from microorganisms under investigation during storage at $4^{\circ} \mathrm{C}$. The obtained results revealed that the effect of Lactobacillus acidophilus on the reduction of Staph.aureus count was almost identical to the effect of Bifidobacteriumlactis. Moreover, Staph.aureus growth persisted till the $6^{\text {th }}$ day of storage, while the organism was completely inhibited at the $8^{\text {th }}$ day of the experiment. Bifidobacteriumlactis was more effective in reducing $E$. coli count through the 8 days of experimental study than Lactobacillus acidophilus. Overall, E. coli could persist till the end of the experimental period in the presence of both probiotics. The maximum reduction \% of $E$. coli count reached $2.0 \log _{10} \mathrm{cfu} / \mathrm{g}(46.95 \%)$ in experimental samples using Bifidobacteriumlactis.

Keywords: Minced meat, Probiotics, Staph. aureus, E. coli, Lactobacillus acidophilus, Bifidobacteriumlactis and Radiation.

(http://www.bvmj.bu.edu.eg)

(BVMJ-34(1): 242-253, 2018)

\section{INTRODUCTION}

Meat products are highly demanded due to their high biological value, reasonable price, agreeable taste and easily serving. On the other hand, these benefits come over the safety and quality of such food items because the vendors have lack information about the basic food safety rules and the principles of health culture. Unfortunately, meat products are subjected to contamination with several types of microorganisms from different sources during preparation, processing as the contamination occurs primarily from raw materials, grinding of meat which will spread exterior contamination essentially throughout the entire muscle mass, post processing handling, cross contamination and/or equipments, lack of refrigeration facilities, ambient temperatures above $20^{\circ} \mathrm{C}$, lack of suitable transportation between the production 
and marketing areas and improper storage temperature (Gibbons et al., 2006).

Staphylococcal food-borne disease (SFD) is one of the most common food-borne diseases worldwide, resulting from the consumption of food that already contaminated by preformed Staph. aureus enterotoxins. Presence of pathogens in food products imposes potential hazard for consumers and causes grave economic loss and loss in human productivity (Jhalka et al., 2014).

E. coli is a human pathogen worldwide associated with meat and meat products, dairy products, vegetables and water. It is recognized as a bacterium causing hemorrhagic colitis. Diarrheal diseases linked to $E$. coli infections are characterized by blood, cramping, abdominal pain, fever, nausea, and vomiting (Abongo and Momba, 2009)

Food preservation is a continuous effort which aims either to eliminate or reduce the out-growth potential of spoilage and pathogenic microorganisms in foods. Until now, approaches to improve food safety have relied on chemical preservatives, antibiotics or through application of more drastic physical treatments using high temperature or refrigeration. Nevertheless, these methods have many drawbacks on the product quality (Rassoli, 2007).

Nowadays, consumers demand high quality, additive-free, safe, healthy, nutritious, vitamin-rich, minimally-processed, freshly taste and functional foods with extended shelf life and a natural or green image (Sarika et al., 2010). Applied research is ongoing to replace chemicals such as nitrite, sulfite, etc. by alternative means such as functional starter and/ or co-cultures for instance $\mathrm{LAB}$ to prolong the shelf-life of foods (De Vuyst, 2000)
The word "probiotic" comes from the Greek words "pro" and "biotic," meaning "for the life." Examples are LAB that are able to produce antimicrobial substances, sugar polymers, sweeteners, aromatic compounds, useful enzymes, or LAB with healthpromoting properties, so called probiotic strains (Gregoria et al., 2013). This represents a way of replacing chemical additives by natural compounds, at the same time providing the consumer with new, attractive food products. The most commonly used probiotic microorganisms are Lactobacillus and Bifidobacterium. A major effort has been made to develop meat-based functional foods using strategies related to increasing the presence of beneficial compounds and limiting those with negative health implications (Carlos et al., 2015).

Therefore, the present study was carried out to study the effect of both Lactobacillus acidophilus and Bifidobacteriumlactis probiotics on improving the bacterial safety of minced beef inoculated with food borne pathogenic bacteria including Staph. aureus and E. coli and stored at $4^{\circ} \mathrm{C}$.

\section{MATERIALS AND METHODS}

\subsection{Collection and preparation of inoculated minced meat sample:}

Raw minced meat sample (1200gm) was collected from supermarket and transported immediately to the laboratory in an ice box. Collected sample was prepared by packing in polyethylene package and sterilized by radiation by being exposed to Gamma radiation of $5 \mathrm{kGy}$ dose (the source of Gamma irradiation was cobalt-60) at the National Center for Radiation Research and Technology (NCRRT) Nasr city, Cairo, Egypt, then divided into two equal portions, which packaged at separate bags (Nassif et al., 2015). 


\subsection{Preparation of pathogenic strains:}

The pathogenic microorganisms used were Staph. aureus NCTC 10788/ ATCC® 6538P and E. coli NCTC 12241/ ATCC® 25922 reference strains (obtained from Becton Dickinson, France). All strains were activated in Food hygiene department Animal Health Research Institute- Dokki, Giza, Egypt. Each strain was deep frozen stored in a cryo protective vial containing preservative solution at $-70{ }^{\circ} \mathrm{C}$. Cryo bead (inoculum) of each strain was cultivated in Tryptic Soy Broth overnight at $35^{\circ} \mathrm{C}$. Then cells were centrifuged for $10 \mathrm{~min}$ at 8000 rpm. Supernatant was discarded, and the sediment represented the cells was washed three times and re-suspended in sterile $0.1 \%$ peptone water. The cells were diluted in peptone water adjusted to obtain the desired inoculum level of $10^{4} \mathrm{cfu} / \mathrm{ml}\left(4 \log _{10} \mathrm{cfu} / \mathrm{ml}\right)$ (Shehata-Amal et al., 2013).

\subsection{Preparation of $L A B$ inoculum:}

Lactobacillus acidophilus was originally obtained from Ch. Hansen's Lab. (Denmark), and Bifidobacteriumlactis was obtained from Australian Research Center Australia, they were reactivated by three consecutive sub culturing on De- Man Regosa and Sharp medium (MRS) broth and agar at $37{ }^{\circ} \mathrm{C}$ for $24 \mathrm{hrs}$. The suspensions were centrifuged at $1.700 \mathrm{Xg}$ for 15 minutes. The supernatant was discarded, and the bacterial pellets were washed twice with phosphate buffered saline (PBS; PH 7.3, 0.01 M) and the concentration of Lactobacillus acidophilus and Bifidobacteriumlactis was adjusted to obtain desired inoculum level of $10^{7} \mathrm{cfu} / \mathrm{ml}(7$ $\left.\log _{10} \mathrm{cfu} / \mathrm{ml}\right)$ (Maha et al., 2015).

\subsection{Sample inoculation:}

Samples of radiated minced meat were divided into two main portions, the first was inoculated with Staph. aureus to reach final concentration of $10^{4} \mathrm{cfu} / \mathrm{g}$ in examined minced meat, then sub divided into three groups, the $1^{\text {st }}$ left as control, the $2^{\text {nd }}$ was inoculated with $10^{7} \mathrm{cfu} / \mathrm{g}$ Lactobacillus acidophilus (Group A), the $3^{\text {rd }}$ was inoculated with $10^{7} \mathrm{cfu} / \mathrm{g}$ Bifidobacteriumlactis (Group B).The second one, was inoculated with E.coli to obtained a final concentration of $10^{4} \mathrm{cfu} / \mathrm{g}$ (4 $\log _{10} \mathrm{cfu} / \mathrm{g}$ ) then, sub divided into three equal groups (200 $\mathrm{g}$ of each); the $1^{\text {st }}$ group was left as control, the $2^{\text {nd }}$ (Group A)inoculated with $10^{7} \mathrm{cfu} / \mathrm{g}$ Lactobacillus acidophilus, while the $3^{\text {rd }}$ (Group B) was inoculated with $10^{7} \mathrm{cfu} / \mathrm{g}$ Bifidobacteriumlactis (Shehata-Amal et al., 2013).

Analysis was conducted from all groups at zero day, $2^{\text {nd }}, 4^{\text {th }}, 6^{\text {th }}$ and $8^{\text {th }}$ days. Counting of Staph. aureus and E. coli load. All experiments were conducted in triplicate on separate days

\subsection{Assessment of microbial growth:}

It was applied according to APHA, 2001, where twenty-five grams of each examined sample was aseptically transferred into stomacher bag and blended with $225 \mathrm{ml}$ sterile peptone water $(0.1 \%)$, then serially diluted under aseptic condition. one $\mathrm{ml}$ of each dilution was aseptically inoculated and spreaded onto Baird parker agar plates, incubated at $35^{\circ} \mathrm{C}$ for $24 \mathrm{hrs}$. for Staph. aureus count as well as Eosin Methylene blue (EMB) agar at $35^{\circ} \mathrm{C}$ for $24 \mathrm{hrs}$ for counting of E. coli.

\subsection{Statistical Analysis:}

A Handbook of Statistical analysis using SPSS (Ver. 20), according to Petrie and Watson (2013).

\section{RESULTS:}


Table (1): Effect of different used probiotics on of Staph. aureus count $\left(\log _{10} \mathrm{cfu} / \mathrm{g}\right)$ experimentally inoculated in radiated minced meat samples.

\begin{tabular}{|c|c|c|c|c|c|}
\hline Tested samples & Zero day & $2^{\text {nd }}$ day & $4^{\text {th }}$ day & $6^{\text {th }}$ day & $8^{\text {th }}$ day \\
\hline Control & $4.26 \pm 0.24$ & $4.45^{\prime \mathrm{A}} \pm 0.26$ & $4.9^{\mathrm{A}} \pm 0.05$ & $5.26^{\prime \mathrm{A}} \pm 0.24$ & $4.88^{\prime \mathrm{A}} \pm 0.09$ \\
\hline Group A* & $4.26 \pm 0.24$ & $3.82^{\prime a " \pm} 0.11$ & $2.49^{\mathrm{a}} \pm 0.2$ & $1.72^{\mathrm{a} a "} \pm 0.12$ & $<1 " \mathrm{a}$ \\
\hline Group B* & $4.26 \pm 0.24$ & $3.65^{\mathrm{a} a} \pm 0.16$ & $2.64^{\mathrm{a} a "} \pm 0.3$ & $1.49 " \mathrm{a} " \pm 0.2$ & $<1 " \mathrm{a"}$ \\
\hline
\end{tabular}

* Group A: samples treated with Lactobacillus acidophilus.

* Group B: samples contaminated with Bifidobacteriumlactis

$*<1 \log _{10} \mathrm{cfu} / \mathrm{g}$ was calculated by zero when applying statistical analysis.

Table (2): Reduction $\log _{10}$ count and \% of Staph. aureus artificially inoculated in radiated minced meat samples treated with different used probiotics:

\begin{tabular}{lllllll}
\hline \multicolumn{2}{l}{ Tested samples } & Zero day & $2^{\text {nd }}$ day & $4^{\text {th }}$ day & $6^{\text {th }}$ day & $8^{\text {th }}$ day \\
Group A & Log count & $4.26 \pm 0.24$ & 0.44 & 1.77 & 2.54 & $<1$ \\
& Reduction \% & $0.0 \%$ & $10.33 \%$ & 41.55 & 59.62 & $100 \%$ \\
\multirow{2}{*}{ Group B } & Log count & $4.26 \pm 0.24$ & 0.61 & 1.62 & 2.77 & $<1$ \\
& Reduction \% & $0.0 \%$ & 14.32 & 38.0 & 65.02 & $100 \%$ \\
\hline
\end{tabular}

* Group A: samples treated with Lactobacillus acidophilus.

* Group B: samples treated with Bifidobacteriumlactis

Table (3): Effect of different probiotics on E. coli count $\left(10^{4} \log _{10} \mathrm{cfu} / \mathrm{g}\right)$ experimentally inoculated in radiated minced meat samples.

\begin{tabular}{llllll}
\hline Tested samples & Zero day & $2^{\text {nd }}$ day & $4^{\text {th }}$ day & $6^{\text {th }}$ day & $8^{\text {th }}$ day \\
Control & $4.26 \pm 0.24$ & $3.9 \pm 0.05$ & $4.49 \pm 0.2$ & $5.42 \pm 0.39$ & $6.25 \pm 0.52$ \\
& & & & & \\
Group A & $4.26 \pm 0.24$ & $3.86 \pm 0.07$ & $3.69 \pm 0.09$ & $3.32 \pm 0.15$ & $3.1 \pm 0.17$ \\
Group B & $4.26 \pm 0.24$ & $3.77 \pm 0.07$ & $3.1 \pm 0.17$ & $2.73 \pm 0.05$ & $2.26 \pm 0.24$ \\
\hline
\end{tabular}

* Group A: samples treated with Lactobacillus acidophilus.

* Group B: samples treated with Bifidobacteriumlactis 
Table (4): Reduction log count and \% of E. coli artificially inoculated in minced beef samples treated with different used probiotics:

\begin{tabular}{lllllll}
\hline Tested samples & Zero day & $2^{\text {nd }}$ day & $4^{\text {th }}$ day & $6^{\text {th }}$ day & $8^{\text {th }}$ day \\
& Log count & $4.26 \pm 0.24$ & 0.4 & 0.57 & 0.94 & 1.16 \\
\multirow{2}{*}{ Group A } & Reduction \% & 0.00 & 9.39 & 13.38 & 22.07 & 27.23 \\
& Log count & $4.26 \pm 0.24$ & 0.49 & 1.16 & 1.53 & 2.0 \\
\multirow{2}{*}{ Group B } & Reduction \% & 0.00 & 11.5 & 27.23 & 35.92 & 46.95 \\
\hline
\end{tabular}

*Group A: samples treated with Lactobacillus acidophilus.

*Group B: samples contaminated with Bifidobacteriumlactis.

\section{DISCUSSION}

Lowering the costs of bio preservation processes may be highly attractive, especially for small economies and developing countries, where food safety, wholesomeness, acceptability and overall quality, have become increasingly important and valued features to consumers even in developing countries (HolzapFel, 2002).

Lactic acid bacteria (LAB) are very important in converting of agricultural products into safe, delicious and shelf stable foods for human consumption. The preservative activity of LAB in foods that has a strong antagonistic effect against food spoilage and pathogenic microorganisms is mainly attributed to competitive exclusion for essential nutrients or adhesion sites of mucous cells, immune modulation, redox modification, accumulation of D-amino-acids and production of extracellular and diffusible antimicrobial metabolites, such as organic acids (lactic, propionic, formic and acetic acids), antifungal compounds (fatty acids or phenyl lactic acid), lysozymes, enzymes (proteases, amylases and lipases) and bacteriocins, which play an essential role in natural preservation (Yasillike et al., 2010). Besides ensuring safety, bacteriocin- producing LAB with their probiotic potentials could also be emerging as a means to develop functional meat products with desirable health benefits. Nevertheless, to be qualified as a candidate probiotic culture (Swetwiwathana and Visessanguan, 2015).

Lactic acid bacteria widely used in food preservation at refrigerator temperatures due to their ability to produce high amount of hydrogen peroxide and/or other antibacterial substances at refrigerator temperatures which inhibit food-borne pathogens and psychrophilic spoilage microorganisms (Alirezaet al., 2016). Since Staph. aureus, which is salt and nitrite tolerant, is also able to grow under anaerobic conditions, there is an increased risk that it will grow and produce toxins (Kaban and Kaya, 2006).

Table (1) explained the effect of the two different probiotics on the growth pattern of Staph. aureus in experimentally inoculated minced beef samples. At zero day, there were no significance difference between all examined groups (control, A and B), they recorded $4.26 \pm 0.24 \log _{10} \mathrm{cfu} / \mathrm{g}$ for each. At the $2^{\text {nd }}$ day of storage, the control group had a higher count $\left(4.45 \pm 0.26 \log _{10} \mathrm{cfu} / \mathrm{g}\right)$ resulted in presence of a significance difference $(\mathrm{P}<0.05)$ with the other two groups $(\mathrm{A}$ and $\mathrm{B})$, 
while there was no significance difference $(\mathrm{P}>0.05)$ between group A $(3.82 \pm 0.11$ $\left.\log _{10} \mathrm{cfu} / \mathrm{g}\right)$ and group B $(3.65 \pm 0.16$ $\left.\log _{10} \mathrm{cfu} / \mathrm{g}\right)$. At the $4^{\text {th }}$ day of storage, the results showed the presence of highly significance difference $(\mathrm{P}<0.01)$ between control group $\left(4.9 \pm 0.05 \log _{10} \mathrm{cfu} / \mathrm{g}\right)$ and both of group A $\left(2.49 \pm 0.2 \quad \log _{10} \mathrm{cfu} / \mathrm{g}\right)$ and B $\left(2.64 \pm 0.3 \log _{10} \mathrm{cfu} / \mathrm{g}\right)$, while the difference between Group A and B still not existed. At the $6^{\text {th }}$ day of storage, the same as $4^{\text {th }}$ day, there was a highly significance difference $(\mathrm{P}<0.01)$ between control group $\left(5.26 \pm 0.24 \log _{10} \mathrm{cfu} / \mathrm{g}\right)$ and both group $\mathrm{A}$ $\left(1.72 \pm 0.12 \log _{10} \mathrm{cfu} / \mathrm{g}\right)$ and B $(1.49 \pm 0.2$ $\left.\log _{10} \mathrm{cfu} / \mathrm{g}\right)$, While still no significant difference $(\mathrm{P}>0.05)$ between group $\mathrm{A}$ and $\mathrm{B}$. At the $8^{\text {th }}$ day of experiment, the significance difference was optimum $(\mathrm{P}<0.00)$ between control group $\left(4.88 \pm 0.09 \log _{10} \mathrm{cfu} / \mathrm{g}\right)$ and both of Group A and B which contained $(<1$ $\left.\log _{10} \mathrm{cfu} / \mathrm{g}\right)$.

Table (2) revealed the $\log _{10} \mathrm{cfu} / \mathrm{g}$ of Staph. aureus count in zero time, in relation to its reduction \% of growth rate in Group (A) which recorded $4.26 \pm 0.24(0.0 \%)$ at zero time, $0.44(10.33 \%)$ at the $2^{\text {nd }}$ day, 1.77 $(41.55 \%)$ at the $4^{\text {th }}$ day, $2.54(59.62 \%)$ at the $6^{\text {th }}$ day. At the $8^{\text {th }}$ day of the experimental time, Staph. aureus growth was inhibited completely $\quad\left(<1 \quad \log _{10} \mathrm{cfu} / \mathrm{g}\right)$ with $100 \%$ reduction rate. While for Group (B), Staph. aureus counts and reduction \% were recorded $4.26 \pm 0.24$ (0.0\%), 0.61 (14.32\%), 1.62 (38\%), $2.77(65.02 \%)$ and $<1 \log _{10} \mathrm{cfu} / \mathrm{g}$ with $100 \%$ reduction rate at zero time, $2^{\text {nd }}, 4^{\text {th }}, 6^{\text {th }}$ and $8^{\text {th }}$ day of storage, respectively. Nearly similar results regarding the effect of probiotics on the reduction of Staph.aureus counts were recorded by several investigators; Sameshimaet al. (1998) who found that Lactobacillus strains could be able to reduce the growth rate and enterotoxin production of Staph. aureus in fermented sausage at $20^{\circ} \mathrm{C}$ and $35^{\circ} \mathrm{C}$., Milani et al. (2003) reported that
Staph. aureus growth was inhibited completely by addition of probiotics to chicken sausage. Kalalouet al. (2004) noticed that staph. aureus population was reached to $<1 \log _{10} \mathrm{cfu} / \mathrm{g}$ in minced meat treated with 7 $\log _{10} \mathrm{cfu} / \mathrm{g}$ probiotics, while control nontreated samples with probiotics, which inoculated with $4 \log _{10} \mathrm{cfu} / \mathrm{g}$ Staph. aureus have reached $5 \log _{10} \mathrm{cfu} / \mathrm{g}$ during 7 days of storage. Moreover Kebary et al. (2005) found that all studied Bifidobacteria strains strongly inhibited the growth of Staph. aureus.

Kaban and Kaya (2006), Erkmen et al. (2009) and Shehata-Amal et al. (2013) found that Staph. aureus was reduced in number in fermented sausage due to the inhibitory effect of probiotic starter culture while the number of Staph.aureus increased by $1 \log$ on the third day in control group.

Bahni, Dhar (2013) reported highly significant $\quad(p<0.01) \quad$ reduction of staphylococci count, which decreased from 2.40 to $1.46 \log _{10} \mathrm{cfu} / \mathrm{g}$ throughout the storage period and the reduction was significant after $14^{\text {th }}$ day of storage in the inoculated minced fish meat previously treated with LAB. Bomdespacho (2014) stated that coagulasepositive staphylococci were inhibited by the addition of Lactobacillus acidophilus. In contrary, Reham, Amin (2012) found that growth of Staphylococcus aureus in minced meat samples stored at $4{ }^{\circ} \mathrm{C}$ was completely inhibited after being treated with Lactobacillus acidophilus in the $3^{\text {rd }}$ day of the experimental time. Also, Sparo et al. (2013) concluded that, no Staph. aureus viable bacteria were detected at $48 \mathrm{~h}$ in ground beef meat post-treated with probiotics. Moreover, Nassif et al. (2015) has been reported that count of staph. aureus was decreased from 6.48 at zero day till reach $3.52 \log _{10} \mathrm{cfu} / \mathrm{g}$ at the $9^{\text {th }}$ day of storage, while the samples completely spoiled at $11^{\text {th }}$ day of storage. 
The effect of different probiotics on count of E. coli experimentally inoculated in radiated minced meat samples was cleared inTable (3) which revealed that at zero time, there were no significance differences between all examined groups (control, $\mathrm{A}$ and B) as all groups recorded almost the same $E$. coli count $\left(4.26 \pm 0.24 \log _{10} \mathrm{cfu} / \mathrm{g}\right)$. Otherwise, there were no significance differences $(\mathrm{P}>0.05)$ between the three experimental groups. At the $2^{\text {nd }}$ day of storage, the control non-treated group recorded $E$. coli count a little bit lower than at the zero time $(3.9 \pm 0.05$ $\log _{10} \mathrm{cfu} / \mathrm{g}$ ) resulted in presence of a low significance difference $(\mathrm{P}<0.05)$ with other two groups (A and $\mathrm{B}$ ), while there was no significance difference $(\mathrm{P}>0.05)$ between group A $\left(3.86 \pm 0.07 \log _{10} \mathrm{cfu} / \mathrm{g}\right)$ and group B. $\left(3.77 \pm 0.07 \log _{10} \mathrm{cfu} / \mathrm{g}\right)$. At the $4^{\text {th }}$ day of storage, the results showed the presence of highly significance difference $(\mathrm{P}<0.01)$ between Control group $\left(4.49 \pm 0.2 \log _{10} \mathrm{cfu} / \mathrm{g}\right)$ and both of group A $\left(3.69 \pm 0.09 \log _{10} \mathrm{cfu} / \mathrm{g}\right)$ and B $\quad\left(3.1 \pm 0.17 \quad \log _{10} \mathrm{cfu} / \mathrm{g}\right)$, while the difference between Group A and B didn't exist. At the $6^{\text {th }}$ day of storage, the same as $4^{\text {th }}$ day, the highly significance difference $(\mathrm{P}<0.01)$ was still persisted between control group $\left(5.42 \pm 0.39 \log _{10} \mathrm{cfu} / \mathrm{g}\right)$ and both of group A $\left(3.32 \pm 0.15 \quad \log _{10} \mathrm{cfu} / \mathrm{g}\right)$ and B $\left(2.73 \pm 0.05 \quad \log _{10} \mathrm{cfu} / \mathrm{g}\right)$, while significance difference still didn't exist between group A and $\mathrm{B}(\mathrm{P}>0.05)$. At the $8^{\text {th }}$ day of experiment period, the significance difference was in optimum condition $(\mathrm{P}<0.00)$ between control group $\left(6.25 \pm 0.52 \log _{10} \mathrm{cfu} / \mathrm{g}\right), 3.1 \pm 0.17$ and $2.26 \pm 0.24$ for Group A and Group B, respectively.

Results illustrated in Table (4) showed the reduction $\log _{10} \mathrm{cfu} / \mathrm{g}$ of $E$. coli in treated groups, count in zero time, in relation to their reduction \% of growth rate in Group (A) which recorded $4.26 \pm 0.24(0.0 \%)$ at zero time, $0.4(9.39 \%)$ at the $2^{\text {nd }}$ day, 0.57 $(13.38 \%)$ at the $4^{\text {th }}$ day, $0.94(22.07 \%)$ at the $6^{\text {th }}$ day and 1.16 with reduction $\%$ represented $27.23 \%$ of $E$. coli count at the $8^{\text {th }}$ day of the experiment. On the other hand, E. coli reduction $\log 10 \mathrm{cfu} / \mathrm{g}$ and percentage for group B was recorded 4.26 $\pm 0.24(0 \%), 0.49$ (11.5\%), 1.16 (27.23\%), 1.53 (35.92) and 2.0 $(46.95 \%)$ at zero time, $2^{\text {nd }}, 4^{\text {th }}, 6^{\text {th }}$ and $8^{\text {th }}$ day of storage, respectively.

Bifidobacteria had more strong inhibitory activity than L. acidophilus towards Gram negative bacteria mainly, Salmonella spp. and $E$. coli. Probiotic LAB couldn't eliminate $E$. coli completely because the organism can resist acidic $\mathrm{pH}$. LAB induce its antagonistic effects against $E$. coli through its ability to produce bacteriocins and bacteriocins like substances which are narrow-spectrum proteinaceous toxins that serve to kill closely related bacteria (Gordon and Obrien, 2006; Majeed et al., 2011 and Berenice Arias et al., 2013).

Bacteriocins are not frequently active against Gram-negative bacteria. The lipopolysaccharide of the outer membrane of this classes of bacteria acts as a permeability barrier for the cell. It is responsible for preventing molecules from reaching the cytoplasmic membrane (Gaoet al., 1999), this explained the cause of persistence of $E$. coli even in the presence of both Lactobacillus acidophilus and Bifidobacteriumlactis and didn't disappeared completely till the end of the experimental period as recorded in the present study. Moreover, similar results were recorded by Mindy et al. (1998) who stated that Lactobacillus lactis was able to reduce the number of $E$. coliO157:H7 in raw chicken breast meat stored at $7^{\circ} \mathrm{C}$ for 7 days.

Pidcock et al. (2002) concluded that Lactobacillus acidophilus and Bifidobacteriumlactis may be used to increase the safety of Hungarian salami because these cultures gave strong inhibition of $E$. coli by more than $2.5 \log$ units. Milani et al. (2003) found that addition of probiotics to chicken 
sausage contained $E$. coli resulted in reduction of $E$. coli growth rate by $2 \log _{10} \mathrm{cfu} / \mathrm{g}$.

In a study on vacuum-packaged fresh ground beef conducted by Smith et al. (2005) they found that the individual $\mathrm{LAB}$ isolates resulted in an average difference of $1.5 \mathrm{log}$ cycles of E. coli $\mathrm{O} 157: \mathrm{H} 7$ after 12 days in ground beef stored at $5^{0} \mathrm{C}$. The authors also concluded that addition of LAB to raw ground beef stored at refrigeration temperatures may be an important intervention for controlling food borne pathogens. In this respect, Hutt (2006) concluded that E. coli was highly suppressed by Bifidobacteriumlactis. The same result obtained byMakras and De Vuyst (2006) who found that the maximum reduction of $E$. coli count reached 2.26 $\log _{10} \mathrm{cfu} / \mathrm{g}(53.05 \%)$ in experimental samples using Bifidobacteriumlactis. In addition, Aksuet al. (2008) found that E. coli $\mathrm{O} 157: \mathrm{H} 7$ which added to pasterma with protective probiotic culture showed approximately a 3$\log$ cycle reduction at the end of the production.

Also, Hoyle et al. (2009) found that $E$. coli O157:H7 was reduced by 2 log cycles after 3 days of storage and by 3 log cycles after 5 days of storage. In addition, Lindqvist andLindblad(2009) reported $1 \quad \log _{10} \mathrm{cfu} / \mathrm{g}$ reduction for E.coli in sausage stored at $8{ }^{\circ} \mathrm{C}$ for 21 days, while Tharmaraj and Shah (2009)stated that the inhibitory effect of all probiotic bacteria was weakest against $E$. Coli and strongest against Staph. aureus which was inhibited to a greater extent, this result agreed with that in the current study. Echeverryet al. (2010) recordedup to $3 \mathrm{log}$ reduction of $E$. coli $\mathrm{O} 157: \mathrm{H} 7$ in meat products stored at $4.4^{\circ} \mathrm{C}$ for 14 or 21 days as compared with control samples. In addition, Hrachyaet al. (2016) determined that the application of $1.4 \times 10^{7} \mathrm{cfu} / \mathrm{ml}$ of lactobacilli to raw ground beef would result in $1 \log$ reductions of $E$. coli $\mathrm{O} 157: \mathrm{H} 7$ during refrigerated storage at $5^{\circ} \mathrm{C}$. Also, Alirezaet al. (2016) reported reduction of $E$. coli $\mathrm{O} 157: \mathrm{H} 7$ by $1-2 \log$ in ground beef stored at $5^{\circ} \mathrm{C}$ for 7 days in plastic vacuum bags depending on $L$. acidophilus ratio.

On contrary, Kalalou et al. (2004) stated that coliforms were reduced from $8 \mathrm{x}$ $10^{2} \mathrm{cfu} / \mathrm{g}$ to $10^{2} \mathrm{cfu} / \mathrm{g}$ after $24 \mathrm{hrs}$ and to less than $1 \mathrm{cfu} / \mathrm{g}$ after 7 days storage of minced meat previously inoculated with $7 \log _{10} \mathrm{cfu} / \mathrm{g}$ lactic acid bacteria (LAB). Moreover, Borowski et al. (2009) explained that $(>=5.0$ $\log$ ) reduction of $E$. coli $\mathrm{O} 157: \mathrm{H} 7$ in examined ground and formed beef jerky previously inoculated with six commercially LAB containing cultures. Jofre et al. (2009) concluded that $E$. coli was unable to grow in experimentally inoculated slices of cooked ham, dry cured ham and marinated beef loin during storage at $4^{\circ} \mathrm{C}$ in the presence of LAB. Also, Berenice Arias et al. (2013) mentioned that, Lactobacillus acidophilus and Bifidobacteriumhad the same antagonistic effect against Escherichia coli O157:H7. In addition, Sparo et al. (2013) through a comprehensive study, found that E. coli O157:H7growth was completely inhibited and the viable cells were not detected at $72 \mathrm{~h}$ in ground beef samples treated with probiotics.

While, Amin-Reham (2012) found that coliform count in ground beef treated with $L$. acidophilus was decreased from initial count of $6.72 \pm 0.43 \mathrm{cfu} / \mathrm{g}$ to $6.0 \pm 1.0 \mathrm{cfu} / \mathrm{g}$ in the first day then began to increase in the $2^{\text {nd }}$ and $3^{\text {rd }}$ day. Casaburi et al. (2016) reported no inhibitory effect of Lactobacillus curvatus 54 M16 on tested Gram-negative bacteria. Moreover, Katie et al. (2017) noticed that the use of a commercial LAB intervention reduced STEC by $0.4 \log _{10} \mathrm{cfu} / \mathrm{cm}^{2}(\mathrm{P}<0.05)$ on intact beef strip loins during refrigeration storage.

These variations in reduction levels of different microorganisms upon using LAB may be attributed to many factors including: the initial count of pathogenic microorganism, 
the concentration of the inoculum of used lactic acid bacteria, the ratio between the LAB and the pathogen which referred as LS: Pathogen ratio ( the higher the ratio the greater the effect ), the type of used probiotic or using mixed culture, the amount of lactic acid, bacteriocin and other antimicrobials produced by the different probiotic strains, the type of the nutritive medium or the food matrix used and the surrounding environment including temperature and $\mathrm{pH}$.

\section{CONCLUSSION:}

The different probiotic strains (L.acidophilus and B.lactis) had antagonistic effect against Staph.aureus and E.coli in ground beefkept at refrigerator

temperature.Moreover,Lactobacillus

acidophilus and Bifidobacteriumlactis had almost identical effect on the reduction of Staph. aureus count, while the organism was completely inhibited at the $8^{\text {th }}$ day of the experiment.

Bifidobacteriumlactis was more effective in reducing $E$. coli count through the 8 days of experimental study thanLactobacillus acidophilus. The maximum reduction $\%$ of $E$. coli count reached 2.0 $\log _{10} \mathrm{cfu} / \mathrm{g}(48.26 \%)$ in experimental samples using Bifidobacteriumlactis .

\section{REFERENCES}

Abongo, B. O. and Momba, M. N. (2009): Prevalence and characterization of Escherichia coli O157:H7 isolates from meat and meat products sold in Amathole District, Eastern Cape Province of South Africa. Food Microbiology J., 26: 173-176.

Aksu, M. I.; Kaya, M. and Oz, F. (2008): Effect of Lactobacillus sakei and Staphylococcus xylosus on the inhibition ofEscherichia coli
O157:H7 in pastirma, a dry-cured meat product. J. Food Safety, 28(1):47-58.

Alireza, G.; Hrachya, H. and Andranik, B. (2016): Elimination of Pathogen Escherichia coli O157:H7 in Ground Beef by a Newly Isolated Strain of Lactobacillus acidophilus during Storage at $5^{\circ} \mathrm{C}$.Applied food biotechnology, 3 (3).

Amin-Reham, A. (2012): Effect of Bio Preservation as a Modern Technology on Quality Aspects and Microbial Safety of Minced Beef. Global J. Biotechnology \& Biochemistry, 7 (2): 38-49.

APHA (American Public Health Association) (2001): Compendium of methods for the microbiological examination of food $4^{\text {th }}$ ed.

Bahni, Dhar (2013): Effect of lactic acid bacteria starter culture on shelf life extension of minced croaker under refrigerated storage. J. Inter academician, 17(1):153-160.

Berenice Arias, O.; De la Luz Reyes, M.; Lilia Navarro, V.; Berenice Solis, C.; Mayra Márquez G.; Gloria Sanchez, S.; Raúl Snell, C. and Raquel Zuñiga, R. (2013): Antagonistic effect of probiotic strains against two pathogens: Salmonella Typhimurium and E. coli $\mathrm{O} 157: \mathrm{H} 7$ resistant to antibiotics, Vol. 11, Art. 5.

Bomdespacho, L.Q.; Cavallini, D.C.U. ; Zavarizi, A.C.M.; Pinto, R.A. and Rossi, E.A. (2014): Evaluation of the use of probiotic acid lactic bacteria in the development of chicken hamburger (Article) . Meat Science.Vol. 97, Issue 3, Pages 332338.

Borowski, A. G.; Ingham, S. C. and Ingham, B. H. (2009): Validation of groundand-formed beef jerky processes 
using commercial lactic acid bacteria starter cultures as pathogen surrogates. J. Food Protection, 72(6):1234-1247.

Carlos, P. C.; Claudia, R. C.; Ana, M. H.; Francisco, J. C. and Cristiano, R. M. (2015): Trends in food sci and tech. 64.120e131. International Food Research J.,21(3): 965-972.

Casaburi, A.; Martino, V. D.; Ferranti, P.; Picariello, L. and Villani, F. (2016): Technological properties and bacteriocins production by Lactobacillus curvatus 54 M16 and its use as starter culture for fermented sausage manufacture. Food Control; 59:31-45.

De Vuyst, L. (2000): Technology aspects related to the applicationof functional starter cultures. Food Technology and Biotechnol.,38: 105-112.

Echeverry, A.; Brooks, J. C.; Miller, M. F.; Collins, J. A.; Loneragan, G. H. and Brashears, M. M. (2010): Validation of lactic acid bacteria, lactic acid, and acidified sodium chlorite as decontaminating interventions to control Escherichia coli O157:H7 and Salmonella TyphimuriumDT 104 in mechanically tenderized and brine-enhanced (non-intact) beef at the purveyor. J. Food Protection ,73(12):2169-2179.

Erkmen, O. (2009): Survival of Staphylococcus aureus and aerobic bacteria in sucuks made from starter culture and Thymbraspicata during manufacturing and storage. Food and Byproducts Processing, 87(1):62-67.

Gao, Y., Belkum, M.J.V. and Stiles, M. (1999): The outer membrane of Gram negative bacteria inhibits antibacterial activity of Brochocin C.
J. Appl. Environ. Microbiol., 65: 4329-4333.

Gibbons, I.; Adesiyun, A.; Nadira, S. and Rahaman, S. (2006): investigation for possible sources of contamination of ready-to-eat meat products with Listeria species and other pathogens in a meat processing plant in Trinidad. Food Microbiol., 23(4): 395-366.

Gordon. D.M. and Obrien, C.L. (2006): Bacteriocin diversity and the frequency of multiple bacteriocin production in Escherichia coli. Pub Med. National Institute of Health, Microbiology, 152(11): 3239-3244.

Gregoria, M.; Viktor, N.; Arun, G. and Yiannis, K. (2013): Immobilization Technologies in Probiotic Food Production. J Food Prot., 68(8):158792.

Holzapfel, W. H. (2002): Appropriate starter culture technologies for small-scale fermentation in developing countries.Int.J Food Microbiol., 25;75(3):197-212.

Hoyle ARBrooks, J. C. ;Thompson , L. D.; Palmore, W.; Stephens ,T. P.; Brashears, M. M. (2009): Spoilage and safety characteristics of ground beef treated with lactic acid bacteria.J Food Prot., 72(6):1234-47.

Hrachya, H.; Alireza, G. and Andranik, B. (2016): Antimicrobial Substances Production at Refrigeration Temperatures by Lactobacillus delbrueckii MH10: A Candidate for Food Biopreservation, International Journal of Nutrition and Food Sciences. 5 (3): 179-184.

Hütt, P.;Shchepetova, J.; Lõivukene,K.;Kullisaar, T. and Mikelsaar, M.(2006): Antagonistic activity of probiotic Lactobacilli and Bifidobacteria against entero- and 
uropathogens. J. Appl. Microbiol.,100(6):1324-32.

Jhalka, K.; Tara, C. S. and Dipendra, T. (2014): Staphylococcus aureus and staphylococcal food -borne Disease: An ongoing challenge in Public Health. Bio Med Research International volume 2014, Article ID 827965,9 pages.

Jofre, A.; Aymerich, T.; Grebol, N. and Garriga, M. (2009): Efficiency of high hydrostatic pressure at $600 \mathrm{MPa}$ against food-borne microorganisms by challenge tests on convenience meat products. LWT - Food Science and Technology; 42(5):924928.

Kaban, G.; Kaya, M. (2006): Effect of starter culture on growth of Staphylococcus aureus Food Control;17(10):797801.

Kalalou, I.; FAID, M. and AHAMI, A.T. (2004): Extending the shelf life of fresh minced camel meat at ambient temperature by Lactobacillus delbruekii subspdelbruekii. Electron. J. Biotechnol. 7 (3): 246-251.

Kebary, K.M.K.; Badawi, R.M.; Badran, I.I. and Hussein, S.A. (2005): Influence of some nutrients and bile salt on the production of antimicrobial agents by Bifidobacteria. Eg.J. of Dairy Sci.,33 (2) 157-170.

Katie, R. K.; Tamra, N. T.; Jessica, C. H.;Alejandro, C.; Davey G.and Matthew T.(2017): Effectiveness of a Commercial Lactic Acid Bacteria Intervention Applied to Inhibit Shiga ToxinProducing Escherichia coli on Refrigerated Vacuum-Aged Beef. Int $\mathrm{J}$ Food Sci.8070515.PMCID: PMC5463119
Lindqvist, R. andLindblad, M.(2009): Inactivation of Escherichia coli,Listeriamonocytogenes and Yersinia enterocolitica in fermented sausages during maturation/storage.Int $\mathrm{J} \quad$ Food Microbiol., 31, 129 (1):59-67.

Maha, M. E.; Mahmoud, E; Nagwa, I. M. K and Mohamed, K. R. (2015): Studies on contamination of dairy products by aflatoxin M1 and its control by probiotics. J. Global Biosciences, 4(1): 1294-1312.

Majeed, H.; Gillor, O.; Kerr, B. and Riley, M.A. (2011): Competitive interactions in Escherichia coli populations: the role of bacteriocins, ISME, J., 5(1): 71-81

Makras, E. and De Vuyst, L. (2006): The in vitro inhibition of Gram-negative pathogenic bacteria by Bifidobacteriais caused by the production of organic acids. Int. Dairy J.16: 1049-1057.

Mindy M Brashears, S SReilly,S E Gilliland (1998):Antagonistic Action of Cells of Lactobacillus lactis toward Escherichia coli $0157: \mathrm{H} 7$ on Refrigerated Raw Chicken Meat.J. Food Protection, 61(2):166-70 .

Milani, L. I. G.; Fries, L. L. M.; Paz, P. B.; Belle, M.; Terra, N. N. (2003): Chicken sausages bioprotection. [Portuguese].Ciencia e Tecnologia de Alimentos, 23(2):161-166.

Nassif, M. R. M.; Azza, S. M. A. and Mona, M. M. A. (2015): Bio-Preservation of Minced Beef Meat as A recent Technology, Egypt. J, Agric. Res., 93, 4(A): 1-9.

Olaoye, O. A. and Dodd, C. E. R. (2010): Evaluation of bacteriocinogenic Pediococcusacidilactici as 
protective culture in the preservation of tsire, a traditional Nigerian stick meat. Journal of Food Safety 30: 867-888.

Petrie, A. and Watson, P. (2013): Statistics for Veterinary and animal science, $3^{\text {rd }}$ ed. Wiley - Blackwell. A John Wiley \& Sons, Ltd., Publication. West Sussex, UK. www.wiley.com/wiley-blackwell.

Pidcock, K.; Heard, G. M. and Henriksson, A. (2002): Application of nontraditional meat starter cultures in production of Hungarian salami. International $\mathrm{J}$. Food Microbiol., 76(1-2): 75-81.

Rasooli, I. (2007): Food preservation. A bio preservative approach. Food Global Science Books, 1:111-136.

Sameshima, T.; Magome, C.; Takeshita, K., Arihara, K.; Itoh, M. and Kondo, Y. ( 1998): Effect of intestinal Lactobacillus starter cultures on the behavior of Staphylococcus aureus in fermented sausage. Int. J. Food Microbiol. , 41(1): 1-7.

Sarika, A. R.; Lipton, A. P. and Aishwarya, M. S. (2010): Bacteriocin production by a new isolate Lactobacillus rhamnosus GP1 under different culture conditions. Advance J. of Food Science and Technology, 2:291-297.

Shehata-Amal, A. Shireen, M. N.; Kawther, A. I. and Wafaa, S. M. (2013): Study the effect of Lactobacillus on the prevalence of some aerobic and anaerobic microorganisms in dry sausage. New York Science J. 6(3): 58-64.

Smith, L.; Mann, J.E.; Harris, K.; Miller, M.F. and Brashears, M.M. (2005): Reduction of Escherichia coli 0157:H7 and Salmonella in ground beef using lactic acidbacteria and the impact on sensory properties. Journal of Food Protection, 68: 1587-1592.

Sparo, M.D.; Confalonieri, A.;Urbizu, L.;Ceci, M. and Sánchez Bruni, S. F. (2013): Bio-preservation of ground beef meat by Enterococcus faecalis CECT7121.Braz J Microbiol., 44(1): 43-49.

Swetwiwathana, A. and Visessanguan, W. (2015): Potential of bacteriocinproducing lactic acid bacteria for safety improvements of traditional Thai fermented meat and human health. Meat Science; 109:101-105.

Tharmaraj, N. and Shah, N. P. (2009): Antimicrobial effects of probiotics against selected pathogenic and spoilage bacteria in cheese-based dips. International Food Research J., 16: 261-276.

Yesillik, S.; Yildirim, N.; Dikici, A.; Yidiz A. andYesillik, S. (2010): Antibacterial effects of somefermented commercial and homemade dairy productsand $0.9 \%$ lactic acid against selected food borne pathogens. Asian J. Anim. Vet. Adv., 6: 189-195. 